\title{
A Heat Stress Application Technique for Reducing Water Loss of Fruits during Storage
}

\author{
Mohammad Safdar Baloch, Tetsuo Morimoto and Kenji Hatou \\ Department of Biomechanical Systems, Faculty of Agriculture, Ehime University, \\ 3-5-7 Tarumi, Matsuyama, Ehime 790-8566, Japan
}

(Received June 1, 2005)

\begin{abstract}
Hot air and hot water are being extensively studied as postharvest heat treatments for retaining freshness and extending shelf life of many fruits and vegetables during storage. In the present study, the best combination of several types of heat stress application methods that minimizes water loss of fruit during storage were investigated, aiming at the practical use. The heat stress application allowed the water loss of the fruit during storage to be successfully reduced. The combinatorial double heat shock treatment where the hot air was first applied for $6 \mathrm{~h}$ at $40^{\circ} \mathrm{C}$ followed by hot water dipping for $6^{-} 12 \mathrm{~h}$ at $40^{\circ} \mathrm{C}$ showed the best performance at the final stage in all other treatments including single hot air, hot water, hot water + hot air and control (nonheated) in minimizing the water loss of oranges during storage. This heat stress technique (HA $+\mathrm{HW}$ ) is useful for successful storage of orange.
\end{abstract}

Keywords : double heat shock, heat stress, hot air, hot water, orange, storage, water loss

\section{INTRODUCTION}

During the past few years, the use of heat treatment technique attained much importance for maintaining freshness of fruits and vegetables during long-term storage (Lurie, 1998; Ferguson et al., 2000). This technique has been applied on a number of fruits and vegetables storage process (Mangan et al., 1998; Morimoto and Hashimoto, 2000; Morimoto et al., 2003; ElAssi, 2004). It is easy to apply, increases firmness and shelf life of fruits (Shellie and Mangan, 1994; Hofman et al., 2000), inhibits ethylene production (Lurie and Klein, 1992; McDonald and McCollum, 1996), controls insect pest and reduces chilling injury (Lurie and Klein, 1992; Paull and McDonald, 1994; Lurie and Sabehat, 1997). Thus, this technique substitutes a non-damaging physical treatment for chemical preservation (Lurie, 1998).

Among heat stress techniques, hot water treatment is generally used for fungal control and disinfestations of insects; vapor heat for insect control and hot air for both fungal and insect control (Lurie, 1998). These heat treatments are used in many countries on commerical scale. But there is still a need of such heating technology that is economically viable and has least thermal impact on product quality has been emphasized (Ferguson et al., 2000). It has been reported that applying heat stress at $40^{-} 50^{\circ} \mathrm{C}$ for $12^{-14} \mathrm{~h}$ at the first stage of the storage process could reduce the water loss (Morimoto et al., 2003). This is probably due to the production of Heat Shock Proteins (HSPs) in the living tissues that eventually attain thermal tolerance (Vierling, 1991) and may lead to the

Corresponding author: Tetsuo Morimoto, fax : +81-89-946-9916, e-mail : morimoto@agr.ehime-u.ac.jp 
reduction of the water loss of fruits during storage (Paull and Chen, 2000). Morimoto et al. (1997 and 2003) found out the optimal treatment of hot air at $40^{\circ} \mathrm{C}$ for $12-24 \mathrm{~h}$ that minimizes the water loss of the fruit during storage. It is, therefore, imperative to find out an optimal heat treatment technique for minimizing the loss of water and maintaining quality of fruits during storage, aiming at the practical application.

In this study, as a next step, the optimal combinatorial uses of the hot air and the hot water were investigated for more effective and practical use of the heat treatment.

\section{MATERIALS AND METHODS}

Amanatsukan oranges (Citrus natsudaidai), abundantly produced in Ehime Prefecture of Japan, were used for the experiment. A total of 147 oranges were taken directly from the farm using 3 fruits in each treatment. The storage chamber used here is a thermo-hygrostat (Tabaiespec, LHU-112M), where the temperature and relative humidity are strictly controlled with the control accuracies of $0.1{ }^{\circ} \mathrm{C}$ and $2 \% \mathrm{RH}$, respectively. The water loss of the fruit was estimated from the weight loss using an electronic balance. Different treatments scenarios were analyzed viz. Hot Air, Hot Water (conventional) and Double Heat Shock Treatments (Hot Air + Hot Water; Hot Air + Cold Water; and Hot Water + Hot Air). In single Hot Water Treatments (HWTs), an appropriate number of fruits were immersed separately in the water bath at $40,41,43$ and $45^{\circ} \mathrm{C}$ with time intervals from $5 \mathrm{~min}$ to $12 \mathrm{~h}$. The submerged fruit were then removed from the water, dried out individually and then shifted to the storage chamber where the temperature was kept constant at $15^{\circ} \mathrm{C}$ for 10 days. Similarly, in single Hot Air Treatments (HATs), the oranges were kept separately under hot air at $40^{\circ} \mathrm{C}$ with exposure time ranging from $30 \mathrm{~min}$ to $72 \mathrm{~h}$ before shifting to the storage chamber at $15^{\circ} \mathrm{C}$ for 10 days to achieve a desired effect. In case of Double Heat Shock Treatments (DHSTs), orange were first kept either in hot air and then in hot water (HA + HW method) or first held in hot water and then in hot air (HW + HA method) before placing into storage chamber. The treatments showing good time-temperature regime in single heat shock were selected for further evaluation under double heat shock method. Control (non-heated) fruit were placed under normal room temperature for first $24 \mathrm{~h}$ and then shifted to the storage chamber at $15^{\circ} \mathrm{C}$. The experimental protocol is given in Table 1.

\section{RESULTS}

The data revealed that a substantial increase of water loss occurred especially in single HWTs during 10 days storage at $15^{\circ} \mathrm{C}$ (Table 2). Under varying temperatures, the overall rate of water loss was initially higher (7.25 and 7.64\%) even under a short hot water exposure for 5 min at 43 and $45^{\circ} \mathrm{C}$ but it declined with the successive heating times of 10 and $15 \mathrm{~min}$ and expedited again from 30 to $60 \mathrm{~min}$. Unlikely, $5.68 \%$ water loss after 5 min exposure was comparatively low but a higher water loss $(7.13 \%)$ was noted after $10 \mathrm{~min}$ at $41^{\circ} \mathrm{C}$ (Table 2). The occurrence of lowest and the highest water loss both after 5 min exposure in HWTs might be the difference in exposure temperatures i.e. 41 and $45^{\circ} \mathrm{C}$. The heating time $10^{-}-15 \mathrm{~min}$ at 43 and $45^{\circ} \mathrm{C}$ might be the transitional phase where the response of orange was fairly static in terms of water loss. As shown in Table 2 that among HATs, only $6-12 \mathrm{~h}$ hot air exposure displayed comparatively good results by reducing the water loss to 2.31 and $2.96 \%$, respectively after 10 days storage. The rest of HATs (from $30 \mathrm{~min}-18 \mathrm{~h}$ hot air exposure) showed more or less uniform rate of water loss (3.40 to $4.85 \%$ ) as compared to 24,48 and $72 \mathrm{~h}$ hot air treatment where a large amount of water was lost in the storage chamber (Table 2). A peer review of data further manifested that different combinations of $\mathrm{HW}+\mathrm{HA} ; \mathrm{HA}+\mathrm{CW}$ and $\mathrm{HA}+\mathrm{HW}$ elucidated very interesting results. However, the maximum water reduction was always associated in treatments where HW was used as primary 
POSTHARVEST HEAT STRESS APPLICATION IN FRUIT

Table 1 Experimental protocol.

\begin{tabular}{|c|c|c|c|}
\hline Method of heating & Exposure tempt & Exposure time & Procedure \\
\hline Hot Water & $41,43,45^{\circ} \mathrm{C}$ & $\begin{array}{l}5,10,15,30,45 \\
\text { and } 60 \mathrm{~min}\end{array}$ & $\begin{array}{l}\text { HW dipping at given temperature and } \\
\text { time and then shifted to storage chamber } \\
\text { at } 15^{\circ} \mathrm{C} \text { for } 10 \text { days }\end{array}$ \\
\hline Hot Air & $40^{\circ} \mathrm{C}$ & $\begin{array}{l}30 \mathrm{~min}, 1,2,3,4, \\
5,6,12,18,24,48 \\
\text { and } 72 \mathrm{~h}\end{array}$ & $\begin{array}{l}\text { HA treatment at given temperature and } \\
\text { time and then shifted to storage chamber } \\
\text { at } 15^{\circ} \mathrm{C} \text { for } 10 \text { days }\end{array}$ \\
\hline Hot Water + Hot Air & $41,43,45^{\circ} \mathrm{C}$ & $\begin{array}{l}5-15 \min +24 h+ \\
24 h\end{array}$ & $\begin{array}{l}\text { HW dipping from } 5-15 \text { min at } 41,43 \text { and } \\
45^{\circ} \mathrm{C} \text {; placed in storage chamber for } 24 \mathrm{~h} \text {; } \\
\text { exposed to hot air at } 40^{\circ} \mathrm{C} \text { for } 24 \mathrm{~h} \text { and fi- } \\
\text { nally shifted to storage chamber at } 15^{\circ} \mathrm{C} \\
\text { for } 10 \text { days }\end{array}$ \\
\hline Hot Air + Hot Water & $40^{\circ} \mathrm{C}$ & $24 h+24 h+12 h$ & $\begin{array}{l}\text { HA treatment at } 40^{\circ} \mathrm{C} \text { for } 24 \mathrm{~h} \text {; placed in } \\
\text { storage chamber for } 24 \mathrm{~h} \text {; dipped in } \mathrm{HW} \\
\text { for } 12 \mathrm{~h} \text { at } 40^{\circ} \mathrm{C} \text { and finally shifted to } \\
\text { storage chamber at } 15^{\circ} \mathrm{C} \text { for } 10 \text { days }\end{array}$ \\
\hline Hot Air + Cold Water & $40^{\circ} \mathrm{C}$ & $24 h+24 h+12 h$ & $\begin{array}{l}\text { HA treatment at } 40^{\circ} \mathrm{C} \text { for } 24 \mathrm{~h} \text {; placed in } \\
\text { storage chamber for } 24 \mathrm{~h} \text {; dipped in } \mathrm{CW} \\
\text { for } 12 \mathrm{~h} \text { at } 14^{\circ} \mathrm{C} \text { and finally shifted to } \\
\text { storage chamber at } 15^{\circ} \mathrm{C} \text { for } 10 \text { days }\end{array}$ \\
\hline Hot Air + Hot Water & $40^{\circ} \mathrm{C}$ & $6 h+24 h+6^{-12 h}$ & $\begin{array}{l}\mathrm{HA} \text { treatment at } 40^{\circ} \mathrm{C} \text { for } 6 \mathrm{~h} \text {; placed in } \\
\text { storage chamber for } 24 \mathrm{~h} \text {; dipped in } \mathrm{HW} \\
\text { for } 6^{-}-12 \mathrm{~h} \text { at } 40^{\circ} \mathrm{C} \text { and finally shifted to } \\
\text { storage chamber at } 15^{\circ} \mathrm{C} \text { for } 10 \text { days }\end{array}$ \\
\hline Hot Air + Hot Water & $42^{\circ} \mathrm{C}$ & $6 h+24 h+6-12 h$ & $\begin{array}{l}\text { HA treatment at } 40^{\circ} \mathrm{C} \text { for } 6 \mathrm{~h} \text {; placed in } \\
\text { storage chamber for } 24 \mathrm{~h} \text {; dipped in } \mathrm{HW} \\
\text { for } 6^{-}-12 \mathrm{~h} \text { at } 42^{\circ} \mathrm{C} \text { and finally shifted to } \\
\text { storage chamber at } 15^{\circ} \mathrm{C} \text { for } 10 \text { days }\end{array}$ \\
\hline Hot Water + Hot Air & $41^{\circ} \mathrm{C}$ & $5 \min +24 h+6 h$ & $\begin{array}{l}\mathrm{HW} \text { dipping for } 5 \mathrm{~min} \text { at } 41^{\circ} \mathrm{C} \text {; placed in } \\
\text { storage chamber for } 24 \mathrm{~h} \text {; exposed to hot } \\
\text { air at } 40^{\circ} \mathrm{C} \text { for } 6 \mathrm{~h} \text { and finally shifted to } \\
\text { storage chamber at } 15^{\circ} \mathrm{C} \text { for } 10 \text { days }\end{array}$ \\
\hline Hot Water + Hot Air & $43,45^{\circ} \mathrm{C}$ & $15 \min +24 h+6 h$ & $\begin{array}{l}\mathrm{HW} \text { dipping for } 15 \mathrm{~min} \text { at } 43 \text { and } 45^{\circ} \mathrm{C} \text {; } \\
\text { placed in storage chamber for } 24 \mathrm{~h} \text {; ex- } \\
\text { posed to hot air at } 40^{\circ} \mathrm{C} \text { for } 6 \mathrm{~h} \text { and finally } \\
\text { shifted to storage chamber at } 15^{\circ} \mathrm{C} \text { for } 10 \\
\text { days }\end{array}$ \\
\hline Control (non-heated) & Room temperature & $24 \mathrm{~h}$ & $\begin{array}{l}\text { At normal room temperature for first } 24 \mathrm{~h} \\
\text { and then shifted to storage chamber at } \\
15^{\circ} \mathrm{C} \text { for } 10 \text { days }\end{array}$ \\
\hline
\end{tabular}

heating medium at 41,43 and $45^{\circ} \mathrm{C}$ for 5,10 and $15 \mathrm{~min}$ (Table 2). In double heat shock treatments, where oranges were first kept under hot air for $24 \mathrm{~h}$ at $40^{\circ} \mathrm{C}$ and then dipped into hot water for $12 \mathrm{~h}$ at $40^{\circ} \mathrm{C}$, the fruit absorbed an average of $1,453 \mathrm{mg}$ and released a total of $3,576 \mathrm{mg}$ of water. Similarly, the fruit absorbed $320 \mathrm{mg}$ of water when first held under hot air for $24 \mathrm{~h}$ at 40 ${ }^{\circ} \mathrm{C}$ and then placed under normal water for $12 \mathrm{~h}$ at $14^{\circ} \mathrm{C}$. In this case, a total of $3,403 \mathrm{mg}$ of water was lost from oranges in the storage chamber at $15^{\circ} \mathrm{C}$. It is evident that the use of HA + HW (6 $\mathrm{h}$ hot air $+6^{-}-12 \mathrm{~h}$ hot water) both at $40^{\circ} \mathrm{C}$ demonstrated outstanding results by minimizing the rate of water loss (1.96 and 1.97\%) after 10 days in the storage chamber. The same heat treatment, where oranges were first held under hot air for $6 \mathrm{~h}$ at $40^{\circ} \mathrm{C}$ and then placed under hot water for 12 $\mathrm{h}$ at $42^{\circ} \mathrm{C}$, also showed lower water loss (total average of $2.26 \%$ ) during storage. The other modified double heat shock treatment like HW $+\mathrm{HA}\left(5^{-}-15 \mathrm{~min}\right.$ hot water at 41 and $43^{\circ} \mathrm{C}+6 \mathrm{~h}$ hot air 


\section{S. BALOCH ET AL.}

Table 2 Response of orange to various exposure times and temperatures during storage.

\begin{tabular}{|c|c|c|c|}
\hline Method of heating & Exposure temperature & Exposure time & $\begin{array}{l}\text { Average total reduction in weight }(\%) \\
\text { after } 10 \text { days in storage chamber at } 15^{\circ} \mathrm{C}\end{array}$ \\
\hline \multicolumn{4}{|c|}{ Single Heat Shock Treatment } \\
\hline \multirow{18}{*}{ Hot Water Treatment } & \multirow{6}{*}{$41^{\circ} \mathrm{C}$} & $5 \mathrm{~min}$ & $5.68 \pm 3.57$ \\
\hline & & $10 \mathrm{~min}$ & $7.13 \pm 0.88$ \\
\hline & & $15 \mathrm{~min}$ & $6.62 \pm 0.23$ \\
\hline & & $30 \mathrm{~min}$ & $6.16 \pm 1.25$ \\
\hline & & $45 \mathrm{~min}$ & $6.34 \pm 1.45$ \\
\hline & & $60 \mathrm{~min}$ & $6.64 \pm 2.0$ \\
\hline & \multirow{6}{*}{$43^{\circ} \mathrm{C}$} & $5 \mathrm{~min}$ & $7.25 \pm 1.05$ \\
\hline & & $10 \mathrm{~min}$ & $6.97 \pm 0.80$ \\
\hline & & $15 \mathrm{~min}$ & $6.20 \pm 2.07$ \\
\hline & & $30 \mathrm{~min}$ & $7.20 \pm 0.49$ \\
\hline & & $45 \mathrm{~min}$ & $6.73 \pm 2.17$ \\
\hline & & $60 \mathrm{~min}$ & $7.37 \pm 0.42$ \\
\hline & \multirow{6}{*}{$45^{\circ} \mathrm{C}$} & $5 \mathrm{~min}$ & $7.64 \pm 0.72$ \\
\hline & & $10 \mathrm{~min}$ & $6.27 \pm 1.21$ \\
\hline & & $15 \mathrm{~min}$ & $6.20 \pm 0.61$ \\
\hline & & $30 \mathrm{~min}$ & $6.87 \pm 2.04$ \\
\hline & & $45 \mathrm{~min}$ & $7.62 \pm 2.96$ \\
\hline & & $60 \mathrm{~min}$ & $7.53 \pm 1.55$ \\
\hline \multirow{12}{*}{ Hot Air Treatment } & \multirow{12}{*}{$40^{\circ} \mathrm{C}$} & $30 \mathrm{~min}$ & $4.15 \pm 0.46$ \\
\hline & & $1 \mathrm{~h}$ & $3.40 \pm 1.27$ \\
\hline & & $2 \mathrm{~h}$ & $4.51 \pm 0.34$ \\
\hline & & $3 \mathrm{~h}$ & $4.34 \pm 0.61$ \\
\hline & & $4 \mathrm{~h}$ & $3.41 \pm 0.86$ \\
\hline & & $5 \mathrm{~h}$ & $4.69 \pm 0.67$ \\
\hline & & $6 \mathrm{~h}$ & $2.31 \pm 1.03$ \\
\hline & & $12 \mathrm{~h}$ & $2.96 \pm 0.34$ \\
\hline & & $18 \mathrm{~h}$ & $4.85 \pm 2.26$ \\
\hline & & $24 \mathrm{~h}$ & $6.87 \pm 1.53$ \\
\hline & & $48 \mathrm{~h}$ & $8.82 \pm 1.55$ \\
\hline & & $72 \mathrm{~h}$ & $12.55 \pm 1.55$ \\
\hline
\end{tabular}

\section{Double Heat Shock Treatments}

\begin{tabular}{|c|c|c|c|}
\hline Method of heating & $\begin{array}{l}\text { HW Exposure } \\
\text { temperature }\end{array}$ & Exposure time & $\begin{array}{l}\text { Average total reduction in weight }(\%) \\
\text { after } 10 \text { days in storage chamber at } 15^{\circ} \mathrm{C}\end{array}$ \\
\hline \multirow{9}{*}{$\begin{array}{l}\text { Hot Water + Hot Air } \\
\text { Treatment }\end{array}$} & \multirow{3}{*}{$41^{\circ} \mathrm{C}$} & $(5 \min +24 h)$ & $6.14 \pm 2.92$ \\
\hline & & $(10 \min +24 h)$ & $8.16 \pm 1.43$ \\
\hline & & $(15 \min +24 h)$ & $8.56 \pm 0.75$ \\
\hline & \multirow{3}{*}{$43^{\circ} \mathrm{C}$} & $(5 \min +24 h)$ & $8.73 \pm 0.10$ \\
\hline & & $(10 \min +24 h)$ & $7.89 \pm 1.05$ \\
\hline & & $(15 \min +24 h)$ & $7.06 \pm 1.75$ \\
\hline & \multirow{3}{*}{$45^{\circ} \mathrm{C}$} & $(5 \min +24 h)$ & $8.11 \pm 0.61$ \\
\hline & & $(10 \min +24 h)$ & $7.66 \pm 0.89$ \\
\hline & & $(15 \min +24 h)$ & $7.61 \pm 3.74$ \\
\hline $\mathrm{HA}+\mathrm{HW}$ & $40^{\circ} \mathrm{C}$ & $(24 h+12 h)$ & $8.56 \pm 0.51$ \\
\hline $\mathrm{HA}+\mathrm{CW}$ & $14^{\circ} \mathrm{C}$ & $(24 h+12 h)$ & $8.66 \pm 0.63$ \\
\hline \multirow{4}{*}{$\begin{array}{l}\text { Hot Air }+ \text { Hot Water } \\
\text { Treatment }\end{array}$} & \multirow{2}{*}{$40^{\circ} \mathrm{C}$} & $(6 h+6 h)$ & $1.96 \pm 0.49$ \\
\hline & & $(6 h+12 h)$ & $1.97 \pm 0.86$ \\
\hline & \multirow{2}{*}{$42^{\circ} \mathrm{C}$} & $(6 h+6 h)$ & $2.54 \pm 0.59$ \\
\hline & & $(6 h+12 h)$ & $2.26 \pm 0.72$ \\
\hline \multirow{3}{*}{$\begin{array}{l}\text { Hot Water + Hot Air } \\
\text { Treatment }\end{array}$} & $41^{\circ} \mathrm{C}$ & $(5 \min +6 h)$ & $2.69 \pm 0.31$ \\
\hline & $43^{\circ} \mathrm{C}$ & $(15 \min +6 h)$ & $2.69 \pm 0.59$ \\
\hline & $45^{\circ} \mathrm{C}$ & $(15 \min +6 h)$ & $3.09 \pm 0.73$ \\
\hline Control (Untreated) & Room temperature & $24 \mathrm{~h}$ & $6.56 \pm 0.66$ \\
\hline
\end{tabular}



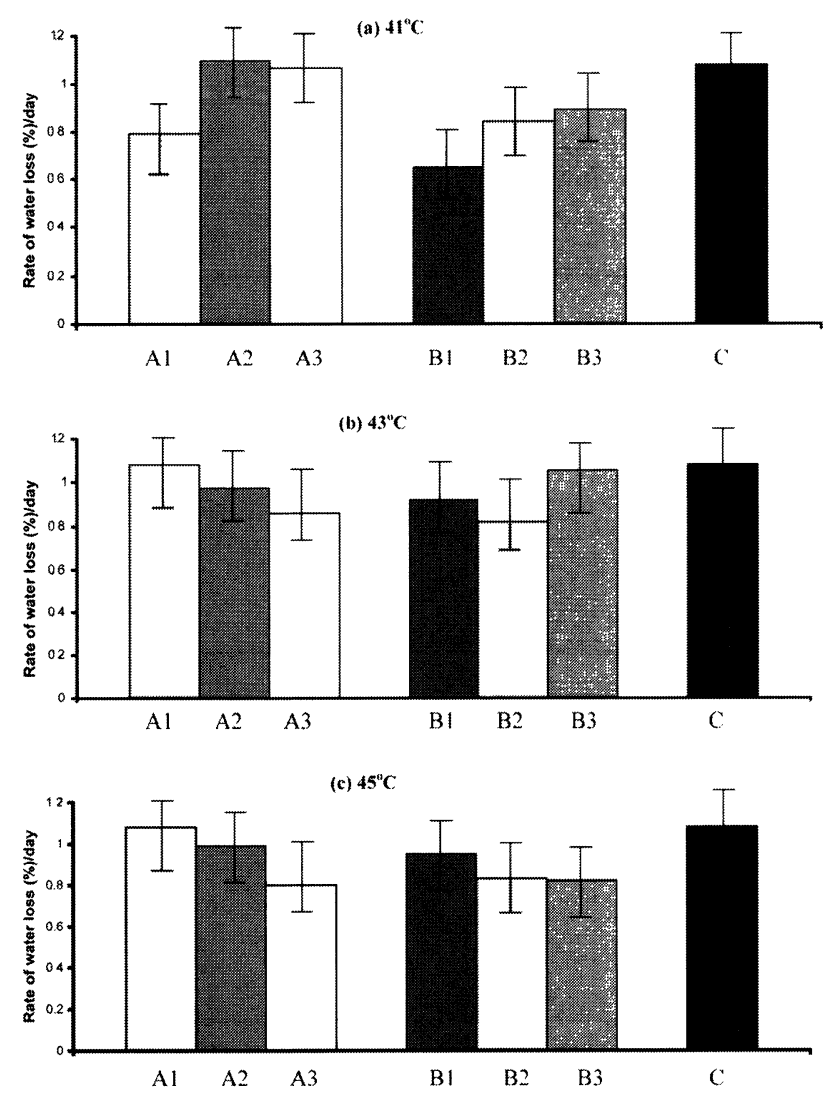

A1, A2, A3: HW 5, 10, 15 minutes B1, B2, B3: HW 5 min HA 24h. HW 10 mint HA $24 \mathrm{~h}$, HW $15 \mathrm{~min}$ HA 24h, C: Control

Fig. 1 Average rate of water loss (\%)/day in weight of orange during storage at $15^{\circ} \mathrm{C}$ using Single Hot Water and Double Heat Shock Treatments $(\mathrm{HW}+\mathrm{HA})$ at 41,43 and $45^{\circ} \mathrm{C}$ for 5,10 and 15 min after 10 days storage.

at $40^{\circ} \mathrm{C}$ ) could not excel $\mathrm{HA}+\mathrm{HW}$ at 40 and $42^{\circ} \mathrm{C}$. The data also show that the rate of water loss $(\%) /$ day decreased progressively in almost all heat treatments than the non-heated control after 10 days. As shown in the figures, the use of HWT for $10 \mathrm{~min}$ at $41^{\circ} \mathrm{C}, \mathrm{HA}+\mathrm{HW}$ and $\mathrm{HA}+\mathrm{CW}$ at water temperatures 40 and $14^{\circ} \mathrm{C}$ resulted in higher water loss than control (Figs. 1a and 4). The application of hot water for $5 \mathrm{~min}$ at 43 and $45^{\circ} \mathrm{C}$ showed same rate of water loss as noted for control (Figs. 1b, c) while all other heat treatments represented lower rate of water loss (\%)/day after 10 days storage at $15^{\circ} \mathrm{C}$ (Figs. 2, 3, 5 and 6). In order to make the difference clear, standard deviation was calculated and then a t-test analysis was carried out. Significant differences were found in most of the treatments especially in single hot air treatment, double heat shock treatment (HA + $\mathrm{HW}$ ) at 40 and $42^{\circ} \mathrm{C}$ than the non-heated (control) at $5 \%$ level of significance after 10 days storage. As far as the response of air temperature of the chamber and surface and center temperatures of the fruit is concerned, it was observed that the first rise of fruit temperature was almost same, however, a short delay about 10-20 min took place in the surface temperature, which revealed nonsignificant difference between the air and surface temperatures of the fruit (Fig. 7). So, the temperature of fruit followed the heat stress. Also, the rate of water loss decreased significantly by using heat stress technique for 12-24 h (Fig. 8). It was found out that after acquiring heat stress, 

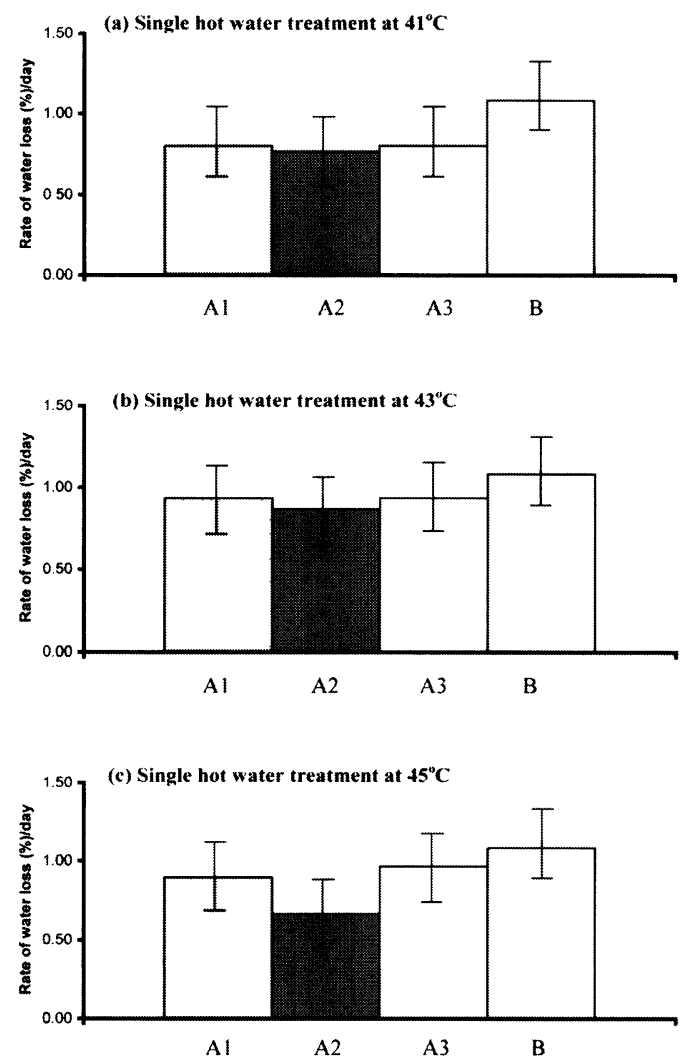

A1: HW 30 minutes, A2: 45 minutes, A3: 60 minutes, B: Control

Fig. 2 Average rate of water loss (\%)/day in weight of orange during storage at $15^{\circ} \mathrm{C}$ using Single Hot Water Treatment at 41,43 and $45^{\circ} \mathrm{C}$ for 30,45 and 60 min after 10 days storage.

the fruit showed lower amount of water loss than control. Therefore, the use of both short-term and long-term heat stress application is very helpful in reducing the rate of water loss of fruit during storage.

\section{DISCUSSION}

In the present study, no difference was noted in fresh weight as well as the weight taken just after HW heating but the higher water loss during 10 days storage explained certain physiochemical changes occurred in the fruit throughout heating process that were subsequently exposed in the storage chamber. Keeping the variable response of fruit to various exposure temperatures and times, the process could be divided into three parts (1) Initial phase - higher water loss during the first 5 min exposure (2) Transitional phase - effective treated time with medium water loss around 10-15 min exposure, and (3) Heat damage phase - excessive water loss after 30 to $60 \mathrm{~min}$ exposure. Heating medium temperature and method always influence the process of thermal energy and it has been observed that the internal heat resistance in fruit during water heating was a more dominant factor in controlling the heat transfer rates than in hot air (Hansen, 1992). The overall higher water loss in HWTs at 43 and $45^{\circ} \mathrm{C}$ from $30^{-} 60$ min might be the variation in the 


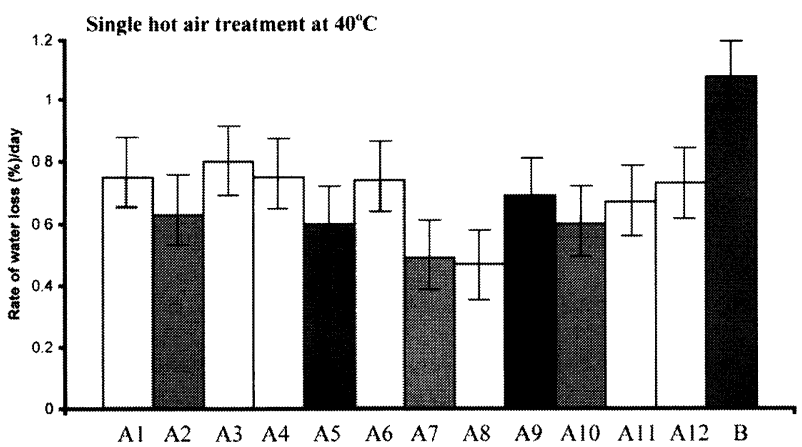

Al: HA 30 min, A2: 1h. A3: 2h, A4: 3h. A5: 4h, A6: 5h. A7: 6h, A8: 12h, A9: 18h, A10: 24h, A11: 48h, A12: $72 \mathrm{~h}$, B: Control

Fig. 3 Average rate of water loss (\%)/day in weight of orange during storage at $15^{\circ} \mathrm{C}$ using Single Hot Air Treatment at $40^{\circ} \mathrm{C}$ from $30 \mathrm{~min} 72 \mathrm{~h}$ after 10 days storage.

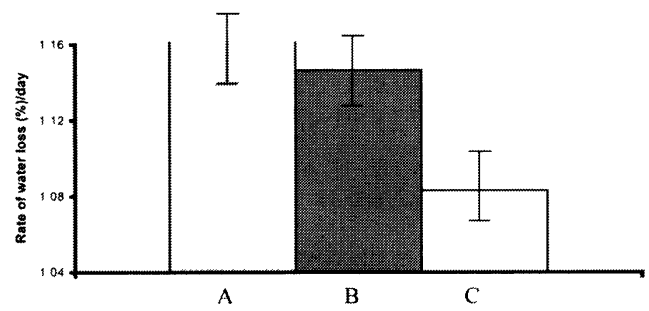

A: HA+HW (24+12h), B: HA+CW (24+12h). C: Control

Fig. 4 Average rate of water loss (\%)/day in weight of orange during storage at $15^{\circ} \mathrm{C}$ using Double Heat Shock Treatments $(\mathrm{HA}+\mathrm{HW}$ and $\mathrm{HA}+\mathrm{CW})$ at water temperature 40 and $14^{\circ} \mathrm{C}$ after 10 days storage.

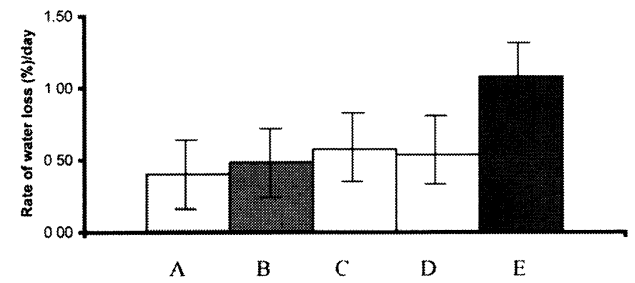

A: HA+HW $(6+6 h), B: H A+H W(6+12 h), C: H A+H W(6+6 h), D: H A+H W(6+12 h)$, E: Control

Fig. 5 Average rate of water loss (\%)/day in weight of orange during storage at $15^{\circ} \mathrm{C}$ using Double Heat Shock Treatments $(\mathrm{HA}+\mathrm{HW})$ at water temperature 40 and $42^{\circ} \mathrm{C}$ after 10 days storage.

thermal diffusivity (Wang et al., 2001). The other possible reason was that the thermotolerance decreases with continued exposure of fruit and temperature at $42^{\circ} \mathrm{C}$ is considered as the limit of induction of HS tolerance (Paull and Chen, 1990). Similarly, Ferguson et al. (1994) noted that continued exposure to $42^{\circ} \mathrm{C}$, though allowed polypeptide synthesis, but also damaged the product quality. Our findings are also inline with Perdue et al. (1998) who exposed cherry fruit to heat treatment at $45^{\circ} \mathrm{C}$ for $15,30,45$ and 60 min and found no induction of HSP70 polypeptides(s) because of the reason that $45^{\circ} \mathrm{C}$ is too high temperature for cherries to produce HSPs. While, as a 


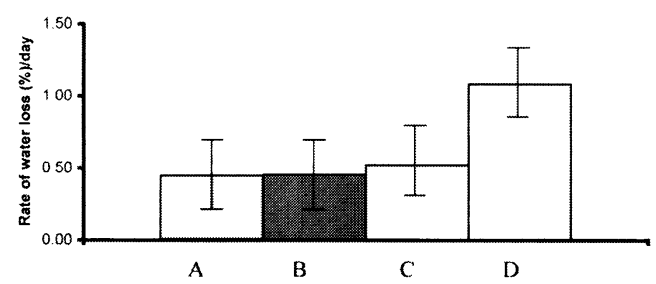

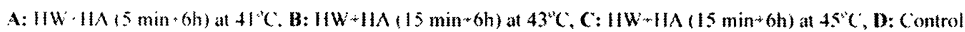

Fig. 6 Average rate of water loss (\%)/day in weight of orange during storage at $15^{\circ} \mathrm{C}$ using Double Heat Shock Treatments (HW + HA) at water temperature 41,43 and $45^{\circ} \mathrm{C}$ after 10 days storage.

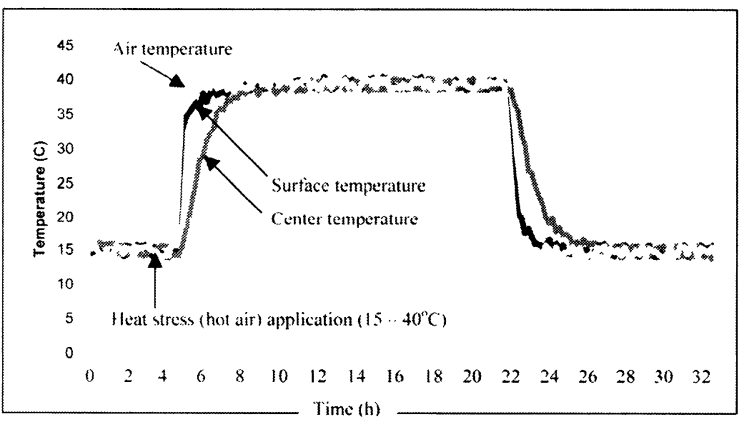

Fig. 7 Response of inside air temperature of the chamber, surface and water temperatures of the fruit.
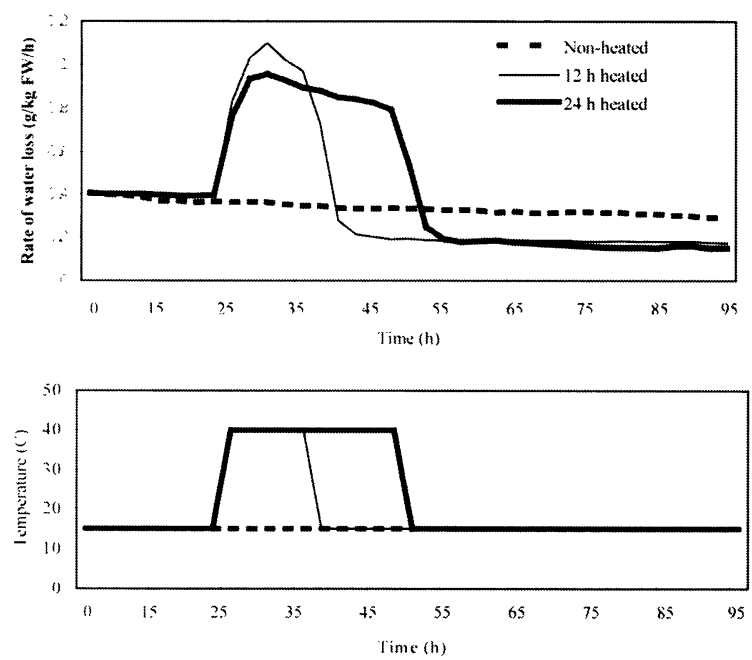

Fig. 8 Short-term response of the rate of water loss of fruit at $40^{\circ} \mathrm{C}$ hot air heat stress application and release.

whole, the lower water loss noted after HW exposure at $41^{\circ} \mathrm{C}$ for $5 \mathrm{~min}$ was probably due to "mild heat" that could cause less damage during subsequent hot or cold treatments (Klein and Lurie, 1992; Lurie, 1998). While observing symptoms, Paull and Chen (1990) reported failure of fruits to ripen fully or softening at a reduced rate at $45^{\circ} \mathrm{C}$. Researchers like Shellie and Mangan (1996) 
suggested vapor heat at $46^{\circ} \mathrm{C}$ for $4.5 \mathrm{~h}$ and hot water at $45^{\circ} \mathrm{C}$ for $42 \mathrm{~min}$ for increased sugar/acid ratio, firmness, colour development and reduce acidity in orange. The differences in HW results, found at $45^{\circ} \mathrm{C}$ in the present study with that of previous findings, might be the differences in cultivars that showed variable responses to heat treatment (Lurie and Sabehat, 1997). Under such conditions Grove et al. (2000) found HW as commercially non-viable treatment, which although reduced chilling injury but could not eliminate it due to variable fruit responses. It has also been reported that HW technique consume many hours in getting a desirable effect due to slow rate of heat transfer (Hansen, 1992). While, Klein and Lurie (1992) preferred hot water treatment due to its low capital investment and high commercial application.

In HATs, initially when the oranges were kept under hot air from $30 \mathrm{~min}$ to $5 \mathrm{~h}$, it showed more water vapors on its surface, which might be due to higher respiration rate in the beginning under higher air temperature of $40^{\circ} \mathrm{C}$ (Lurie and Klein, 1992). It also showed that the heating process and high water thrashing could be instigated even after a shorter to few hours' hot air exposure. By comparing the results obtained in the HW and HATs, it is obvious that the mode of moisture loss in both the heating techniques was same i.e. higher initial water loss, fairly static during transitional phase and excessive water loss after the midpoint. In general, the rate of water loss was higher as after HAT for $72 \mathrm{~h}$. It might be the result of longer heat stress at $40^{\circ} \mathrm{C}$, whereas the less heating time $\left(6^{-12} \mathrm{~h}\right)$ caused lower water loss in the storage chamber (Gaffney and Armstrong, 1990).

The best optimal temperature for orange storage was realized by making certain adjustments in exposure time using double heat shock technique. As shown previously that the rate of water loss was found to be minimum in DHSTs where oranges were first held under hot air for $6 \mathrm{~h}$ and then immersed under hot water for $6^{-} 12 \mathrm{~h}$ both at $40^{\circ} \mathrm{C}$ before placing into storage chamber at $15^{\circ} \mathrm{C}$. The possible reason for such a lower water reduction in this treatment could be the use of optimum hot air exposure for $6 \mathrm{~h}$ in the beginning process and subsequent submergence of fruit into hot water that might have either compensated the loss of water that occurred during the hot air exposure or caused certain physio-chemical changes in the fruit to acquire double heat shock stress in storage chamber at $15^{\circ} \mathrm{C}$. In the present study, the combination of $\mathrm{HA}+\mathrm{HW}$ was found better than that of HW + HA might be due to the effect of the strength of heat stress. The hot air treatment (HA) produces stronger stress than the hot water (HW) if the temperature is same. The combination of the stronger stress (HA) during the first stage and the smaller stress (HW) during the latter stage is more effective to reduce the water loss of fruit. It seems that this phenomenon is the same as the decrease in water loss after the heat stress application (stronger stress). But, the inverse combination of the smaller stress (HW) during the first stage and the stronger stress (HA) during the second stage resulted in a higher water loss. Therefore, the combination of the first stronger stress (stress application) and the second non-stress (stress release) is effective to reduce the water loss of fruit during storage. In all DHSTs, the use of $6 \mathrm{~h}$ hot air exposure appeared as an appropriate time therefore by making certain adjustments in water temperatures and time, the technique could successfully be used for storage of other agricultural commodities.

\section{CONCLUSION}

The rate of water loss was generally lower than the non-heated control using single HWTs at $41^{\circ} \mathrm{C}(5,30,45 \mathrm{~min}), 43^{\circ} \mathrm{C}(15 \mathrm{~min})$ and $45^{\circ} \mathrm{C}\left(10^{-} 15 \mathrm{~min}\right)$. Similarly, the HATs from $30 \mathrm{~min}-$ $18 \mathrm{~h}$ also showed lower moisture loss than the untreated control during 10 days storage. The loss of water was reduced substantially by using the combinatorial DHSTs where the fruit was first placed under hot air for $6 \mathrm{~h}$ followed by hot water dipping for $6^{-12} \mathrm{~h}$ both at $40^{\circ} \mathrm{C}$. This treatment showed the best performance in minimizing the water loss of orange during storage. Therefore, this new technique is useful for successful storage of orange. 


\section{S. BALOCH ET AL.}

\section{REFERENCES}

ElAssi, N. M. 2004. Alleviating chilling injury and maintaining quality of tomato fruit by hot water treatment. Emir. J. Agric. Sci. 16: 1-7.

Ferguson, I. B., Lurie, S., Bowen, J. H. 1994. Protein synthesis and breakdown during heat shock of cultured pear cells. Plant Physiol. 104: 1429-1437.

Ferguson, L. B., Ben-Yohoshua, S., Mitcham, E. J., McDonald, R. E., Lurie, S. 2000. Post harvest heat treatments: Introduction and workshop summary. Postharvest Biol. Tech. 21: 1-6.

Gaffney, J. J., Armstrong, J.W. 1990. High-temperature forced-air research facility for heating fruits for insect quarantine treatments. J. Econ. Entomol. 83: 1959-1964.

Grove, T., De Beer, M.S., Steyn, W. P. 2000. Further evaluation of heat shock treatments to develop tolerance to quarantine cold treatments. S. Afr. Avocade growers Assoc. Yearbook 23: 103-108.

Hansen, J. D. 1992. Heating curve models of quarantine treatments against insect pests. J. Econ. Entomol. 85: $1846-1854$.

Hofman, P. J., Tubbings, B. A., Adkins, M. F., Meiburg, G. F., Woolf, A. B. 2000. Hot water treatment improves "Hass" avocado fruit quality after cold disinfestations. Postharvest Biol. Tech. 24: 183-192.

Klein, J. D., Lurie, S. 1992. Prestorage heating of apple fruit for enhanced postharvest quality: Interaction of time and temperature. Hortic. Sci. 27: 326-328.

Lurie, S., Klein, J. D. 1992 . Ripening characteristics of tomato stored at $12^{\circ} \mathrm{C}$ and $2{ }^{\circ} \mathrm{C}$ following a poststorage heat treatment. Sci. Hortic. 51: 55-64.

Lurie, S., Sabehat, A. 1997. Pre-storage temperature manipulations to reduce chilling injury in tomatoes. Postharvest Biol. Tech. 11: 57-62.

Lurie, S. 1998. Review: Post harvest heat treatments. Postharvest Biol. Tech. 14: 257-269.

Mangan, R. K., Shellie, K. C., Ingle, S. J., Firko, M. J. 1998. High temperature forced-air treatments with fixed time and temperature for "Dancy" tangerines, "Valencia" oranges, and "Rio Star" grapefruit. J. Econ. Entomol. 91: 933-939.

McDonald, R. E., McCollum, T. G. 1996. Pre-storage heat treatment influence free sterols and flavor volatiles of tomatoes stored at chilling temperature. J. Am. Soc. Hortic. Sci. 121: 531-536.

Morimoto, T., Purwanto, W., Suzuki, J., Hashimoto, Y. 1997. Optimization of heat treatment for fruit during storage using neural networks and genetic algorithms. Comput. Electron. Agric. 19: 87-101.

Morimoto, T., Hashimoto, Y. 2000. An intelligent control for greenhouse automation, oriented by the concepts of SPA and SFA-an application to a post-harvest process. Comput. Electron. Agric. 29: 3-20.

Morimoto, T., Tu, K., Hatou, K., Hashimoto, Y. 2003. Dynamic optimization using neural networks and genetic algorithms for tomato cool storage to minimize water loss. Transactions of the ASAE. 46: 1151-1159.

Paull, R. E., Chen, N. J. 1990. Heat shock response in field grown ripening papaya fruit. J. Am. Soc. Hortic. Sci. 115: $623-631$.

Paull, R. E., McDonald, R. E. 1994. Heat and cold treatments. In "Insect Pests and Fresh Horticultural Products: Treatments and Responses" (ed. by Paull, R. E., Armstrong, J. W.) CAB International, Wallington, U.K., p 191-223.

Paull, R. E., Chen, N. J. 2000. Heat treatment and fruit ripening. Postharvest Biol. Tech. 21: 21-37.

Perdue, D. O., Mitcham, E. J., Neven, L. G. 1998. Transient expression of HSC70 in cherry fruit subjected to heat. J. Agric. Food Chem. 46: 4447-4450.

Shellie, K. C., Mangan, R. L. 1994. Post-harvest quality of "Valencia" orange after exposure to hot, moist, forced air for fruit fly disinfestations. Hortic. Sci. 29: 1524-1527.

Shellie, K. C., Mangan, R. L. 1996. Tolerance of red fleshed grapefruit to constant or stepped temperature, forced-air quarantine heat treatment. Postharvest Biol. Tech. 7: 151-159.

Vierling, E. 1991. The roles of heat shock proteins in plants. Ann. Rev. Plant Physiol. Plant Mol. Biol. 42: 579-620.

Wang, S., Tang, J., Cavalieri, R. P. 2001. Modeling fruit internal heating rates for hot air and hot water treatments. Postharvest Biol. Tech. 22: 257-270. 